\title{
PENGARUH PENGETAHUAN PASAR MODAL SYARIAH DAN MOTIVASI INVESTASI TERHADAP MINAT INVESTASI KAUM MILENIAL GARUT DI PASAR MODAL SYARIAH
}

\author{
Adzkya Dzulda Alfarauq \\ Manajemen Keuangan Syariah, UIN Sunan Gunung Djati Bandung \\ dzuldaa@gmail.com \\ Deni Kamaludin Yusup \\ Manajemen Keuangan Syariah, UIN Sunan Gunung Djati Bandung \\ dkyusup@uinsgd.ac.id
}

\begin{abstract}
This research is motivated by the low investment interest of millennials in Garut City, this is assumed because of the lack of socialization regarding investment in the capital market for millennials. So that the researcher has the aim to analyze the effect of Islamic capital market knowledge and investment motivation on the investment interest of Garut millennials in the Islamic capital market. The data analysis technique used in this study is multiple linear regression. Then, the data used comes from collecting questionnaires or research questionnaires and literature study. The population in this study is the millennial generation in Garut, with a sample of 112 respondents. The results obtained are that the knowledge of the capital market has a significant influence on the investment interest of Garut millennials. However, it is different from the influence of investment motivation which does not have a significant effect on the investment interest of Garut millennials. Finally, together, capital market knowledge and investment motivation have a significant influence on the investment interest of Garut millennials with an influence contribution of $17.7 \%$, meaning that $82.3 \%$ of investment interest is influenced by other factors outside of this study.
\end{abstract}

Keywords: Sharia Capital Market Knowledge, Investment Motivation, Investment Interest

\begin{abstract}
Abstrak
Penelitian ini dilatarbelakangi oleh, rendahnya minat investasi kaum milenial Kota Garut, hal ini diasumsikan karena minimnya sosialisasi mengenai investasi di pasar modal untuk kaum milenial. Sehingga peneliti memiliki tujuan untuk menganalisis pengaruh pengetahuan pasar modal syariah dan motivasi investasi terhadap minat investasi kaum milenial Garut di pasar modal Syariah. Teknik analisis data yang digunakan dalam penelitian ini adalah regresi linear berganda. Kemudian, data yang digunakan berasal dari pengumpulan kuesioner atau angket penelitian dan studi kepustakaan. Populasi dalam penelitian ini adalah generasi milenial di Garut, dengan sampel sebanyak 112 responden. Hasil penilitian yang didapatkan adalah pengetahuan pasar modal memiliki pengaruh yang signifikan terhadap minat investasi kaum milenial Garut. Namun, berbeda dengan pengaruh motivasi investasi yang tidak berpengaruh signifikan terhadap minat investasi kaum milenial Garut. Terakhir, secara bersama-sama pengetahuan pasar modal dan motivasi investasi memiliki pengaruh yang signifikan terhadap minat investasi kaum milenial Garut dengan kontribusi pengaruh sebesar sebesar 17,7 \%, artinya sebesar $82,3 \%$ minat investasi dipengaruhi oleh faktor-faktor lain diluar penelitian ini.
\end{abstract}

Kata kunci: Pengetahuan Pasar Modal Syariah, Motivasi Investasi, Minat Investasi 


\section{Pendahuluan}

Pasar modal syariah merupakan aktivitas jual beli efek syariah suatu perusahaan yang go public, seluruh produk dan mekanisme transaksinay tidak bertentangan di syariat islam, yaitu alQuran dan al-Hadits. Selain itu, pasar modal syariah ini merupakan bagian dari pasar modal yang telah ada namun bedanya menerapakan prinsip-prinsip syariah dalam segala aktivitas perdagangannya. Prinsip syariah disini maksudnya adalah terbebas dari Maghrib (maisyir, gharar dan riba), karena pasar modal konvensional disinyalir banyak mengandung larangan tersebut sehingga umat muslim yang ingin berinvestasi di sana meragukan kehalalan dan keharamannya. (Soemitra, 2009)

Kebutuhan umat muslim akan transaksi perdagangan saham yang sesuai prinsip-prinsip syariah diakomodir dengan kehadiran pasar modal syariah ini. Calon investor tidak perlu khawatir karena seluruh saham yang dalam pasar modal syariah ini sudah terjamin kehalalan dan keharamannya. Dengan begitu, Pemerintah Indonesia hanya perlu lebih giat lagi dalam menarik investor untuk melirik investasi di pasar modal syariah indonesia, baik dari investor lokal maupun mancanegara seperti negara-negara Asia Timur Tengah yang notabenenya muslim. (Soemitra, 2009).

Kehadiran stock exchange di suatu negara menjadi salah satu angin segar bagi pendanaan perusahaan baik pemerintah maupun swasta. Karena di pasar modal ini merupakan transaksi orang yang kelebihan dana dengan yang kekurangan dana. Menerbitkan obligasi atau surat utang dan Sukuk dapat menjadi pilihan pemerintah saat pemerintah membutuhkan dana. Kemudian, perusahaan swasta dapat menerbitkan saham atau obligasi juga untuk di jual secara terbuka kepada masyarakat agar mendapatkan suntikan dana (Nasution , 2015).

Pasar modal syariah sendiri di Indonesia tetap berada di bawah naungan Bursa Efek Indonesia, hanya saja memiliki indeks saham syariah berupa Jakarta Islamic Index dan Index Saham Syariah Indonesia (ISSI). Perusahaan-perusahaan yang terdaftar di kedua indeks tersebut sudah dipastikan memenuhi syarat sebagai saham syariah. Semenjak keberadaaan Bursa Efek di Indonesia ini, seluk beluk investasi di pasar modal syariah menjadi mudah diakses oleh masyarakat. Namun, walaupun pasar modal Indonesia sudah memasuki usia yang ke 25 tahun, belum terdapat peningkatan yang signifikan dari total investor, informasi ini diperoleh dari artikel berita tirto.id.

Keberminatan warga indonesia dalam menanamkan modalnya di pasar modal masih bisa dibilang cukup rendah yaitu sebesar $0,15 \%$ penduduk Indonesia, angka ini tentu rendah jika dibandingkan dengan minat investasi dari negara lain (Pajar \& Pustikaningsih, 2017). Persentase tersebut tentunya menjadi catatan penting bagi pegiat ekonomi syariah, karena angka tersebut peminat investasi di pasar modal secara keseluruhan, jika dikonversikan lagi dalam pasar modal syariah tentu persentasenya akan lebih kecil. Maka bagi pegiat ekonomi Syariah khususnya para investor di Indonesia untuk bisa menumbuhkan minat masyarakat untuk memulai berinvestasi di pasar modal syariah.

Kaum milenial merupakan harapan bagi kemajuan ekonomi di sektor pasar modal. Kaum milenial adalah orang-orang yang saat ini berusia 20-40 tahun atau menurut para ahli yang sudah lebih dahulu melakukan penelitian adalah tahun kelahiran 1980 an sampai dengan awal 2000 an.. Seiring arus globalisasi ini kaum milennial Indonesia mempunyai banyak peluang karena perkembangan teknologi, maka dari itu seharusnya kaum millennial khususnya kaum millennial Garut harus memanfaatkan kondisi sekarang. Menurut Badan Pusat Statistik (BPS) wilayah Garut (Editor, 2020), kaum milenial Garut yang berusia sekitar 20-35 tahun tercatat sebanyak 551.894, hal ini baiknya menjadi perhatian bagi pemerintah untuk pemberdayaan terhadap 
mereka salah satunya berupa memberikan sosiasliasi mengenai Investasi pasar modal Syariah guna meningkatkan minat investasi di pasar modal syariah. Peneliti tidak menemukan data-data sebelumnya apakah Kota Garut pernah melakukan sosialisasi terkait pasar modal yang dikhususkan bagi kaum milenial. Selain itu, survei awal peneliti pada sekitar 50 responden kaum milenial menjawab belum pernah mengikuti seminar terkait pasar modal sehingga pengetahuan mereka terkait investasi hanya didapatkan dari internet. Maka dari itu, artikel ini akan menganalisis seberapa besar pengaruh pengetahuan investasi dan motivasi investasi terhadap minat investasi kaum millennial Garut di pasar modal Syariah.

\section{Metode}

Pada penelitian kali ini, penelitian kuantitatif merupakan bentuk penelitian yang digunakan. Penelitian ini bersifat deskriptif dan explanatory survey. Penelitian kuantitatif biasanya berupa penelitian survey yang menjelaskan hubungan antara variable bebas dengan variable terikat yaitu variable pengetahuan investasi terhadap variable minat investasi. Data-data yang digunakan dalam artikel kali ini berasal dari responden kuesioner dimana menggunakan skala likert dan dokumentasi berupa studi kepustakaan. Populasi dalam penelitian ini ialah kaum millennial Garut yang berusia sekitar 20-35 tahun dengan jumlah 551.894 orang. Dikarenakan jumlahnya terlalu banyak, maka sumber data penelitian ditentukan berdasarkan sampel, teknik sampel accidental sampling yang termasuk teknik nonprobability sampling dan jumlah sampel ditentukan menggunakan rumus slovin. Sehingga diperoleh sampel sebanyak 112 orang. Teknis analisis data yang di pakai ialah menggunakan analisis regresi berganda (Sugiyono, 2013).

\section{Hasil dan Pembahasan}

Analisis data pada penelitian ini basednya menggunakan analisis regresi linear berganda, dimana tujuannya untuk mengetahui pengaruh variabel independen terhadap variabel dependen baik secara parsial maupun simultan. Berikut hasil analisis regresi linear berganda:

\section{Tabel 1 Hasil Uji Regresi Berganda}

Coefficients ${ }^{a}$

\begin{tabular}{|c|c|c|c|c|c|}
\hline \multirow{2}{*}{ Model } & \multicolumn{2}{|c|}{} & $\begin{array}{c}\text { Standardized } \\
\text { Coefficients }\end{array}$ & \multirow{2}{*}{$\mathrm{t}$} & \multirow{2}{*}{ Sig. } \\
\cline { 2 - 6 } & $\mathrm{B}$ & Std. Error & Beta & & \\
\hline$($ Constant $)$ & 3.084 & .683 & & 4.518 & .000 \\
\hline$\left(\mathrm{X}_{1}\right)$ & .240 & .068 & .358 & 3.516 & .001 \\
\hline$\left(\mathrm{X}_{2}\right)$ & .066 & .066 & .102 & 1.001 & .319 \\
\hline
\end{tabular}

a. Dependent Variabel : Minat Investasi (Y)

Sumber: hasil output SPSS versi 20

Merujuk pada hasil statistik menggunakan SPSS dengan Y adalah minat investasi, kemudian $\mathrm{X} 1$ ialah pengetahuan pasar modal syariah, dan X2 merupakan motivasi investasi, persamaan regresi linear berganda yang didapatkan adalah :

$$
\mathrm{Y}=3.084+0.240 \mathrm{X}_{1}+0.066 \mathrm{X}_{2}+\mathrm{e} .
$$

Interpretasi dari model tersebut adalah sebagai berikut :

a. $a=3.084$ 
Konstanta dari model regresi ditunjukan dengan nilai 3.084. hal tersebut memiliki arti bahwa tanpa kontribusi dari pengatahuan pasar modal $\left(\mathrm{X}_{1}\right)$ dan motivasi investasi $\left(\mathrm{X}_{2}\right)$ maka nilai minat investasi yang diperoleh sebesar 3.084 satuan.

b. $b_{1}=0.240$

Angka $b_{1}$ ini menunjukan perubahan angka diberikan oleh variabel pengatahuan pasar modal $\left(\mathrm{X}_{1}\right)$ terhadap minat investasi $(\mathrm{Y})$. Koefisien regresi variabel pengatahuan pasar modal (X1) memiliki nilai positif. Hal ini berarti setiap pengetahuan pasar modal mengalami peningkatan $1 \%$ maka akan terjadi perubahan nilai pada minat investasi $(\mathrm{Y})$ sebesar 0.240 .

c. $b_{2}=0.066$

Nilai $b_{2}$ ini menunjukan besarnya perubahan yang diberikan oleh variabel Motivasi Investasi $\left(\mathrm{X}_{2}\right)$ terhadap variabel minat investasi $(\mathrm{Y})$. Koefisien regresi variabel Motivasi Investasi $\left(\mathrm{X}_{2}\right)$ memiliki nilai positif. Hal ini mengundikasikan setiap motivasi investasi berubah angkanya naik atau turun $1 \%$ atau satu satuan maka minat investasi juga akan berubah 0.006 .

\subsection{Pengaruh Pengetahuan Pasar Modal Syariah terhadap Minat Investasi}

Sarana yang menjadi tempat bertemunya antara penjual dan pembeli efek disebut pasar modal. Bursa Efek menjadi wadah yang resmi sebagai tempat yang memfasilitasi penjualan dan pembelian saham, obligasi dan surat-surat berharga lainnya baik milik pemerintah atau perusahaan. Bagi perusahaan, ketika mereka menjual sebagain saham atau keseluruhan saham yang dimiliki oleh perusahaannya secara terbuka bertujuan untuk mencari dana tambahan untuk perusahaannya. Maka pembeli saham tersebut memiliki hak kepemilikan atas perusahaan berdasarkan persentase saham yang ia beli (Komaruddin, 1996).

Pengetahuan Investasi merupakan pemahaman dasar yang harus dimiliki seseorang sebelum melakukan proses investasi agar terhindar dari kerugian yang tidak diinginkan. Pengetahuan investasi meliputi tujuan dilakukannya investasi, risiko yang harus dihadapi, keuntungan yang diharapkan dan pengetahuan tentang pasar modal. Dalam transaksi investasi atau jual beli saham di pasar modal, seorang calon investor membutuhkan bukan hanya pengetahuan, tapi juga pengalaman, dan insting bisnis yang kuat agar dapat menganalisis saham atau efek lainnya yang menguntungkan dan rendah risikonya (Halim, 2005).

Pada prinsipnya, calon investor harus memiliki pengetahun dasar seputar investasi itu sendiri. Bukan hanya mengenai pasar modalnya tapi indeks apa yang akan dibeli, bagaimana sahamnya, seperti apa perusahannya, dan apakah berlandaskan prinsip syariah atau tidak. Dengan pengetahun tersebut, para calon investor tentu akan aman bertransaksi di pasar modal syariah karena terhindar dari praktik haram dalam muamalah yaitu riba, maisyir dan gharar, selain itu investasi tidak hanya didasarkan pada ikut-ikutan karena calon investor bisa menganalisis sahamnya (Pajar \& Pustikaningsih , 2017).

Pengetahuan pasar modal syariah bagi kaum milenial ini sangatlah penting untuk memperkuat keyakinan dalam berinvestasi. Edukasi dan informasi Pasar modal perlu di tingkatkan agar mempercepat pertumbuhan minat investasi di Indonesia. Kesadaran mengenai investasi di pasar modal Syariah akan berdampak positif bagi perkenomian Indonesia di sector pasar modal.

Berdasarkan penjelasan di atas, sejalan dengan hasil penelitian yang didapatkan. Hasil pengujian hipotesis yang menunjukan adanya pengaruh variable Pengetahuan Pasar Modal Syariah (X1) terhadap Variable Minat Investasi Kaum Milenial Garut (Y) secara parsial dapat di lihat pada table berikut: 
Tabel 2 Hasil Uji $t$ Pengaruh Pengetahuan Pasar Modal terhadap Minat Investasi Coefficients $^{a}$

\begin{tabular}{|c|c|c|c|c|c|}
\hline \multirow{2}{*}{ Model } & \multicolumn{2}{|c|}{} & $\begin{array}{c}\text { Standardized } \\
\text { Coefficients }\end{array}$ & \multirow{2}{*}{$\mathrm{t}$} & \multirow{2}{*}{ Sig. } \\
\cline { 2 - 6 } & $\mathrm{B}$ & Std. Error & Beta & & \\
\hline (Constant) & 3.084 & .683 & & 4.518 & .000 \\
\cline { 2 - 6 }$\left(\mathbf{X}_{1}\right)$ & .240 & .068 & .358 & $\mathbf{3 . 5 1 6}$ & $\mathbf{. 0 0 1}$ \\
\cline { 2 - 6 }$\left(\mathrm{X}_{2}\right)$ & .066 & .066 & .102 & 1.001 & .319 \\
\hline
\end{tabular}

a. Dependent Variabel : Minat Investasi (Y)

Sumber: hasil output SPSS versi 20

Merujuk pada tabel di atas, dapat dilihat variabel $\mathrm{X}_{1}$ memiliki nilai $t 3,516$ dengan Sig 0,001. Hal ini berarti, pengetahuan pasar modal berpengaruh signifikan secara parsial terhadap minat investasi kaum milenial kota Garut karena memenuhi kriteria 3,516>1,982 dan 0,0001< 0,005. Penelitian serupa pernah dilakukan oleh (Merawati \& Putra, 2015), dan hasil yang didapatkan pun memiliki efek positif dan berpengaruh signifikan.

\subsection{Analisis Pengaruh Motivasi Investasi terhadap Minat Investasi}

Motivasi adalah suatu keadaan untuk melakukan kegiatan - kegiatan tertentu guna mencapai tujuan dalam pribadi seseorang yang mendorong keinginan individu. Motivasi pada diri seseorang diperlihatkan dengan perilaku yang mengarah pada pencapaian tujuan tertentu (Merawati \& Putra, 2015).

Motivasi merupakan suatu proses di mana individu mengetahui kebutuhannya dan menentukan tindakan untuk memenuhi kebutuhan tersebut. Tindakan tersebut menunjukkan perbedaan dalam intensitas perilaku konsumen (Malik, 2017). Motivasi pada seseorang tentu harus ada pendorongnya, menurut beberapa ahli dua hal yang menjadi pendorong utama motivasi adalah pengetahuan dan keahlian. Beberapa penelitian mengatakan motivasi investasi merupakan suatu kondisi yang menpush individu dalam melakukan transaksi investas. Maka dari itu, untuk menumbukan minat seseorang dalam berinvestasi seseorang memerlukan dorongan berupa motivasi investasi (Nisa \& Zulaika, 2017).

Motivasi dalam melakukan kegiatan investasi di pasar modal syariah sangat di perlukan tentunya bagi kaum milenial sebagai salah satu faktor kemajuan sektor pasar modal ini. Hal tersebut agar mereka mendapatkan kepercayaan diri lebih sehingga kegiatan berinvestasi tetap stabil. Pada investor milennial motivasi ini berdampak selain dari kepercayaan diri meningkat melainkan juga menjadi pelopor bagi milennial lainya yang belum tertarik berinvestasi.

Merujuk pada teori di atas, hasil penelitian ini menunjukkan hal yang berbeda dalam penelitian ini, beriukut hasil secara parsial uji t:

Tabel 3 Hasil Uji $t$ Pengaruh Motivasi Investasi terhadap Minat Investasi Coefficients $^{\mathrm{a}}$

\begin{tabular}{|c|c|c|c|c|c|}
\hline \multirow[t]{2}{*}{ Model } & & & $\begin{array}{l}\text { Standardized } \\
\text { Coefficients }\end{array}$ & \multirow[t]{2}{*}{$\mathrm{t}$} & \multirow[t]{2}{*}{ Sig. } \\
\hline & B & Std. Error & Beta & & \\
\hline \multirow{3}{*}{$\begin{array}{c}\text { (Constant) } \\
\left(\mathrm{X}_{1}\right) \\
\left(\mathbf{X}_{2}\right)\end{array}$} & 3.084 & .683 & & 4.518 & .000 \\
\hline & .240 & .068 & .358 & 3.516 & .001 \\
\hline & .066 & .066 & .102 & 1.001 & .319 \\
\hline
\end{tabular}

a. Dependent Variabel : Minat Investasi (Y)

Sumber: hasil output SPSS versi 20 
Merujuk pada tabel di atas, dapat dilihat variabel $\mathrm{X}_{1}$ memiliki nilai $t 3,516$ dengan Sig 0,001. Hal ini berarti, pengetahuan pasar modal berpengaruh signifikan secara parsial terhadap minat investasi kaum milenial kota Garut karena memenuhi kriteria 3,516 > 1,982 dan 0,0001< 0,005 .

Tabel di atas merupakan hasil uji $t$ yang dilakukan menggunakan SPSS. Hasil yang diperoleh adalah uji $t$ sebesar 1,001 dengan Sig sebesar 0,319. Hasil tersebut menunjukkan motivasi investasi tidak berpengaruh signifikan terhadap minat investasi kaum milenial Garut, karena hasilnya adalah $1,001<1,1982$ dan $0,319>0,005$.

Hasil penelitian menunjukkan bahwa motivasi investasi tidak berpengaruh dalam mendorong minat investasi kaum milenial Garut di pasar modal syariah. Menurut hemat peneliti, hal ini dikarenakan karakteristik kaum milenial yang konsumtif dan gemar menghabiskan waktu bersama teman-temannya sehingga motivasi investasi tadi tergerus dan modal yang bisa dialokasikan pada pasar modal malah habis karena konsumsitif. Selain itu, kaum milenial Garut menurut hasil analisis peneliti, lingkungan sekitarnya tidak cukup kuat untuk memotivasi dalam hal berinvestasi di pasar modal syariah. Penelitian serupa pernah dilakukan oleh (Merawati \& Putra, 2015), dan hasil yang didapatkan pun memiliki efek positif dan berpengaruh signifikan. Namun juga bertolak belakang dengan penelitian yang dilakukan oleh (Amhalmad \& Irianto, 2019) dimana, motivasi memiliki pengaruh yang signifikan terhadap minat investasi.

\subsection{Pengaruh Pengetahuan Pasar Modal Syariah dan Motivasi Investasi Terha- dap Minat Investasi Kaum Milenial Garut di Pasar Modal Syariah}

Generasi milenial menjadi bagian yang dominan dalam demograsi indonesia saat ini. Generasi milenial memiliki karakteristik yang berbeda daripada generasi lainnya dalam hal investasi. Perbedaan karakteristik ini salah satunya didukung oleh kemajuan teknologi yang kemudian mengubah gaya hidup dan sikap kritis, sehingga dapat menilai dan memilih suatu peluang usaha salah satunya dalam sektor pasar modal. Kemudahan mendapatkan informasi menjadi keunggulan utama bagi generasi milenial. Namun, jika kemudahan memperoleh pengetahuan pasar modal atau investasi tidak dibarengi dengan motivasi yang kuat baik dari diri sendiri maupun lingkungan sekitar maka minat investasi tidak akan terjadi

Diera globalisasi ini, mahasiswa yang menjadi bagian dari kaum milenial dan masyarakat pada umumnya sudah lazim mempraktikkan investasi di pasar modal. Asumsi ini dapat dilihat dari kenyataan bahwa masyarakat berinvestasi walaupun tidak memiliki modal besar. Sementara, kalangan mahasiswa yang masih menggunakan uang kiriman dari orang tua juga bisa melakukan investasi. Mahasiswa melakukan investasi dengan membagi yang kiriman yang didapatkan dari kiriman orang tua dengan menginvestasikan terlebih dahulu setengahnya sisanya digunakan untuk keperluan sehari-hari, hal ini yang disebut perubahan pola pikir kaum milenial. Hal ini menunjukan bahwa investasi bukan hanya keinginan dan menunjukkan kegengsian namun juga dianggap sebagai sebuah kebutuhan.

Seperti yang telah dijelaskan sebelumnya, keinginan yang didapatkan oleh seseorang secara sadar dan karena tertarik dengan sesuatu di sebut minat. Ketika seseorang telah memiliki minat terhadap sesuatu maka seseorang tersebut akan berusaha mencapai atau mendapatkan sasaran tersebut, begitu pula dengan investasi. Ketika seseorang tertarik atau berminat terhadap investasi, maka akan mendorong seseorang mencari pemahaman, mengasah keterampilan untuk melakukan investasi (Syah, 2008). 
Sesuai dengan paparan teori di atas, penelitian ini memiliki hasil uji $t$ yaitu minat investasi dipengaruhi secara signifikan oleh faktor pengetahuan pasar modal dan motivasi investasi. Berikut hasilnya dapat dilihat dari tabel di bawah ini:

Tabel 4 Hasil Uji F Pengaruh Pengetahuan Pasar Modal dan Motivasi Investasi terhadap Minat Investasi

ANOVA $^{\mathrm{b}}$

\begin{tabular}{|c|c|c|c|c|c|}
\hline Model & Sum of Squares & df & Mean Square & F & Sig. \\
\hline Regression & 14.419 & 2 & 7.210 & 11.684 & $.000^{\mathrm{b}}$ \\
Residual & 67.260 & 109 & .617 & & \\
Total & 81.679 & 111 & & & \\
\hline
\end{tabular}

a. Predictors: (Contans), Motivasi Investasi $\left(\mathrm{X}_{2}\right)$, Pengetahuan Pasar Modal $\left(\mathrm{X}_{1}\right)$

b. Dependent Variabel: Minat Investasi (Y)

Sumber: hasil output SPSS versi 20

Sesuai dengan hasil output SPSS for windows di atas, hasil uji F menunjukkan angka yang tinggi dari $\mathrm{F}$ tabel yang menjadi acuan kriteria berpengaruh atau tidaknya. Hasil diperoleh F hitung pada tabel adalah 11, 684 dengan Sig 0,000. Angka ini memenuhi kriteria 11,684 > 2,19 dan 0,000 < 0,005. Maka dari itu, penelitian ini membuktikan bahwa secara bersama-sama pengetahuan pasar modal dan motivasi investasi berpengaruh signifikan terhadap minat investasi kaum milenial Garut.

Kontribusi pengaruh dan kekuatan hubungan motivasi investasi dan pengetahuan pasar modal terhadap minat investasi dapat dilihat melalui tabel di bawah ini

Tabel 5 Hasil Koefisien Determinasi dan Korelasi Berganda Pengaruh Pengetahuan Pasar Modal dan Motivasi Investasi terhadap Minat Investasi

Model Summary

\begin{tabular}{|l|c|c|c|c|}
\hline Model & $\mathrm{R}$ & R Square & $\begin{array}{c}\text { Adjusted R } \\
\text { Square }\end{array}$ & $\begin{array}{c}\text { Std. Error of } \\
\text { The Estimate }\end{array}$ \\
\hline 1 & $.402^{\mathrm{a}}$ & .177 & .161 & .786 \\
\hline
\end{tabular}

a. Predictors: (Contans), Motivasi Investasi $\left(\mathrm{X}_{2}\right)$, Pengetahuan Pasar Modal $\left(\mathrm{X}_{1}\right)$

b. Dependent Variabel: Minat Investasi (Y)

Sumber: hasil output SPSS versi 20

Hasil koefisien determinasi pada penelitian ini adalah 0,177 atau sama dengan 17,7\%. Artinya, kontribusi pengaruh yang diberikan oleh pengetahuan pasar modal dan motivasi investasi terhadap minat investasi hanya 17,7\% dimana sebesar $82,3 \%$ ada faktor-faktor lain yang mempengaruhinya.Kemudian kekuatan hubungannya dapat dilihat dari nilai $\mathrm{R}$ sebesat 0,402. Nilai tersebut menunjukan terdapat hubungan yang sedang antar variabel Pengetahuan Pasar Modal dan Motivasi Investasi dengan variabel Minat Investasi karena berada pada interval $0.40-0.60$.

Seseorang yang tertarik atau berminat dengan investasi, maka orang tersebut akan berusaha menggali informasi tentang jenis investasi yang diinginkan dan saham seperti apa yang akan dibeli. Terdapat ciri-ciri seorang berminat terhadap investasi, ia akan mempelajari keuntungan, kelemahan, dan kinerja saham yang akan dibeli. Tahun 2018, kaum milenial yang berada pada rentang usia 18 sampai dengan 25 tahun memiliki pertumbuhan investor yang cukup tinggi karena peningkatannya adalah 116,78\%. Apabila dibandingkan dengan tahun 2016 dan 2017, angka ini dapat dikatakan tinggi. Melihat hasil tersebut, ini dapat menjadi strategi baru bagi pemerintah untuk memfokuskan peningkatan minat investasi pada kaum milenial dengan 
rentang usia tersebut (Indonesia, 2020).Hasil penelitian ini sejalan dengan hasil penelitian (Pajar \& Pustikaningsih , 2017) yang menyatakan secara simultan motivasi investasi dan pengetahuan pasar modal berpengaruh terhadap minat investasi di pasar modal. Peneliti tidak menemukan penelitian kontra yang tidak mendukung hasil penelitian ini. Artinya, kedua variabel memang mempengaruhi minat investasi walaupun berbeda objek penelitian.

\section{Kesimpulan}

Penelitian ini menghasilkan kesimpulan; pertama, secara parsial pengetahuan pasar modal berpengaruh signifikan terhadap minat investasi kaum milenial Garut dengan $3.516>$ 1.982 dan nilai signifikansi $0.000<0.05$; kedua, motivasi investasi secara parsial tidak berpengaruh signifikan terhadap minat investasi kaum milenial Garut dengan $1.001<1.982$ dan nilai signifikansi $0.319>0.05$; dan ketiga, secara simultan pengetahuan pasar modal dan motivasi investasi berpengaruh signifikan terhadap minat investasi kaum milenial Garut pada pasar modal syariah dengan nilai $11.684>2.19$ dan nilai signifikan $0.000<0.05$. Kontribusi pengaruh keduanya sebesar $17,7 \%$, dimana sebesar $82,3 \%$ ada faktor-faktor lain yang mempengaruhinya dan kekuatan hubungannya berada pada interval sedang. Penelitian ini berimplikasi pada pemerintah Garut harus memberikan pengetahuan lebih terkait investasi di pasar modal pada khususnya kaum milenial karena dapat dilihat pengetahuan memberikan pengaruh terhadap minat investasi kaum milenial Garut. Kemudian, dengan pengetahun yang mendalam akan memunculkan motivasi yang mendorong minat investasi lebih serius lagi.

\section{Referensi}

Amhalmad, I., \& Irianto, A. (2019). Pengaruh Pengetahuan Investasi dan Motivasi Investasi terhadap Minat Berinvestasi Mahasiswa Pendidikan Ekonomi Fakultas Ekonomi Universitas Negeri Padang. Jurnal EcoGen, Vol. 2 No. 4, 734-746.

Editor. (2020). Jumlab Warga Kabupaten Garut. Retrieved from https:/ /garutkab.bps.go.id/statictable/2017/05/31/...

Halim, A. (2005). Analisis Investasi. Jakarta: Salemba Emban Patria.

Indonesia, B. E. (2020). Pengetahuan Dasar dan Mekanisme Mengenai Pasar Modal Syariah . Retrieved from https://www.idx.co.id/investor/pengantar-pasar-modal.

Komaruddin, A. (1996). Dasar-dasar Manajemen Investasi. Jakarta: Rineka Cipta.

Malik, A. D. (2017). Analisis Faktor-faktor yang Mempengaruhi Minat Masyarakat Berinvestasi di Pasar Modal Syariah melalui Bursa Galeri Investasi UISI. Jurnal Ekonomi dan Bisnis Islam, Vol. 3, No. 1, 61-84.

Merawati, L. K., \& Putra, I. M. (2015). Kemampuan Pelatihan Pasar Modal Memoderasi Pengatuhan Investasi dan Penghasilan pada Minat Berinvestasi Mahasiswa. Jurnal Ilmiah Akuntansi dan Bisnis, Vol. 10, No. 2, 105-118.

Nasution, Y. S. (2015). Peranan Pasar Modal dalam Perekonomian Negara. Human Falah: Jurnal Ekonomi dan Bisnis Islam, Vol. 2, No.1, 95-112.

Nisa, A., \& Zulaika, L. (2017). Pengaruh Pemahaman Investasi, Modal Minimal Investasi dan Motivasi Terhadap Minat Mahasiswa Berinvestasi di Pasar Modal (Studi pada Mahasiswa Sekolah Tinggi Kesuma Negara). Jurnal Penelitian Teori \& Terapan Akuntansi (PETA), Vol. 2, No. 2, 22-35. 
Pajar, R. C., \& Pustikaningsih , A. (2017). Pengaruh Motivasi Investasi dan Pengetahuan Investasi terhadap Minat Investasi di Pasar Modal pada Mahasiswa FE UNY. Jurnal Profita, Vol. 5, No. 1, 1-16.

Soemitra, A. (2009). Bank dan Lembaga Keuangan Syariah . Jakarta: Kencana.

Sugiyono. (2013). Metode Penelitian Kuantitatif Kualitatif dan R\&D . Bandung: Alfabeta.

Syah, M. (2008). Psikologi Pendidikan . Bandung: PT. Remaja Rosdakarya. 